Scientific Electronic Archives

Issue ID: Sci. Elec. Arch. Vol. 14 (11)

November 2021

DOI: http://dx.doi.org/10.36560/141120211428

Article link: https://sea.ufr.edu.br/SEA/article/view/1428

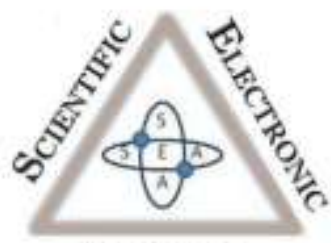

Archives

ISSN 2316-9281

\title{
Produtividade com sementes pré-inoculadas de soja em períodos antes da semeadura
}

\section{Yield with seeds in pre-inoculation of soybean in time's precedence to sowing}

\author{
Cassiano Spaziani Pereira \\ Universidade Federal do Mato Grosso, Campus Sinop \\ caspaziani@yahoo.com.br \\ Yan Carlos Schineider \\ Universidade Federal de Mato Grosso, Campus Sinop \\ Ivan Vilela Andrade Fiorini \\ Universidade Federal de Mato Grosso, Campus Sinop \\ Helder Duarte PereiraAutônomo \\ Adriano Alves da Silva \\ Centro Universitário de Formiga \\ Anderson Lange \\ Universidade Federal de Mato Grosso, Campus Sinop
}

\begin{abstract}
Resumo. A prática de inoculação das sementes de soja com bactérias fixadoras de nitrogênio representou um grande avanço na produção da cultura, como as do gênero Bradyrhizobium que são capazes de captar o nitrogênio existente na atmosfera e convertê-lo em $\mathrm{N}$ assimilável pelas plantas. A pré-inoculação, que constitui em inocular a bactéria fixadora de $\mathrm{N}$ nas sementes com maior antecedência a semeadura é uma prática já utilizada em alguns países. Porém, a utilização dessa técnica depende da habilidade da bactéria em sobreviver nas sementes e do tipo de tratamento realizado no beneficiamento. O objetivo do trabalho foi determinar o tempo "ideal" entre a inoculação e a semeadura na cultura da soja. A cultivar utilizada foi a M 8372 IPRO, e a pré-inoculação foi feita em cinco datas diferentes; $1,4,6,7$ e 8 dias antes da semeadura. O delineamento experimental foi inteiramente casualizado (DIC) com quatro repetições. Determinou-se a área foliar, teor de clorofila, número de folhas, o número de grãos por vagem, o peso de mil grãos e produtividade. Com a análise dos resultados verificou-se diferença em algumas características. Não foram notadas diferenças estatísticas entre a produção da testemunha com os demais tratamentos, porém houve ganhos de até 700 $\mathrm{kg} / \mathrm{ha}$ com o inoculante, mostrando que a pré-inoculação pode trazer ganhos econômicos se realizada corretamente.

Palavras chave: Glycine max, pré-inoculação, produtividade
\end{abstract}

\begin{abstract}
The practice of inoculation of soybean seeds with nitrogen-fixing bacteria represented a major advance in crop production, such as those of the genus Bradyrhizobium that are able to capture existing nitrogen in the atmosphere and convert it into $\mathrm{N}$ assimilable by plants. The pre-inoculation, which consists in inoculating the $\mathrm{N}$-fixing bacteria in seeds with greater precedence to sowing, is a practice already used in some countries. However, the use of this technique depends on the ability of the bacteria to survive in the seeds and the type of treatment performed in the benefit. The objective of the study was to determine the "ideal" time between inoculation and sowing in soybean culture. The cultivar used was M 8372 IPRO, and pre-inoculation was done at five different dates; 1, 4, 6, 7 and 8 days before sowing. The experimental delineation was entirely casualised with four repetitions. The foliar area, chlorophyll content, number of leaves, number of grains per vage, weight of 1,000 grains and yield were determined. With the analysis of the results there was a difference in some characteristics. No statistical differences were observed between the production of treatment without inoculation with the rest, however, there were gains of up to $700 \mathrm{~kg} / \mathrm{ha}$ with the inoculant, showing that pre-inoculation can bring economic gains if performed correctly.

Keywords: Glycine max, pré-inoculation, yield
\end{abstract}




\section{Introdução}

A soja exerce um papel muito importante na alimentação animal e humana, servindo de fonte de proteína vegetal além de grande impulsionadora da economia brasileira, sendo a cultura mais importante dentro do nosso agronegócio. Segundo dados do Ministério da Economia, a soja em grãos é o produto líder em exportação no Brasil, sendo que em 2020 foram comercializados US\$ 25,7 bilhões, tendo a China como principal destino.

A importância do nitrogênio $(N)$ na soja é muito clara, por ser parte constituinte de proteínas e ácidos nucléicos, moléculas essenciais para funcionamento de todos os processos biológicos, sendo o nutriente exigido em maior quantidade pelas plantas. Na cultura da soja a demanda em $\mathrm{N}$ é elevada, principalmente devido ao grande teor de proteína nos grãos, que sozinhos apresentam um teor médio de $6,5 \% \mathrm{~N}$, ou seja, é necessário $65 \mathrm{~kg}$ de $\mathrm{N}$ para produzir $1000 \mathrm{~kg}$ de grãos de soja. Contando caule, raízes e folhas, que juntas consomem pelo menos $15 \mathrm{~kg}$ de $\mathrm{N}$, a necessidade chega a $80 \mathrm{~kg}$ de $\mathrm{N}$ (MENDES et al., 2007).

Apesar da riqueza de $\mathrm{N}_{2}$ na atmosfera terrestre, os organismos que fazem parte do grupo dos eucariotos (animais e plantas) não conseguem usufruir diretamente deste elemento devido à tripla ligação existente entre os átomos de $\mathrm{N}$, conhecida por ser muito forte. Somente alguns organismos procariotos conseguem reduzir enzimaticamente o nitrogênio da atmosfera em amônia, podendo essa ser absorvida e incorporada para o crescimento e manutenção das células. Estes organismos são denominados diazotróficos e 0 processo encarregado pela incorporação de $\mathrm{N}$ à biomassa é chamado de fixação biológica de nitrogênio (FBN) (MARIN et al., 1999).

No processo de inoculação essas bactérias, denominadas de forma popular como rizóbios, são incorporadas às sementes antes do plantio, garantindo uma associação simbiótica entre eles. Essa simbiose é facilmente observada, pois nas raízes das leguminosas são formados os chamados nódulos, estruturas especializadas para o processo biológico. Nessas estruturas, íons de hidrogênio $\left(\mathrm{H}^{+}\right)$, abundantes nas células das bactérias, são incorporados à amônia sintetizada, transformando em íons amônio $\left(\mathrm{NH}_{4}{ }^{+}\right)$que então são distribuídos para a planta hospedeira em diversas formas de $\mathrm{N}$ orgânico (HUNGRIA; CAMPO; MENDES, 2007).

A inoculação mais tradicional desses rizóbios é via semente, porém essa técnica pode perder eficiência, especialmente pela aplicação conjunta de inseticidas e fungicidas, os quais podem causar toxidez às bactérias e danos às sementes. Como método alternativo para diminuir esses efeitos negativos e possibilitar a inoculação, uma prática que tem sido adotada é a aplicação de rizóbio no sulco de semeadura, na mesma operação de distribuição das sementes (VIEIRA NETO, 2008).

A inoculação das sementes antes da comercialização, ou inoculadas alguns dias antes da semeadura (pré-inoculação), são práticas usadas há algumas décadas em outros países, para diversas culturas, além da soja (DEAKER et al., 2004; HERRIDGE, 2008), se consolidando como uma prática que tende a ser cada vez mais utilizada em lavouras de soja no país (EMBRAPA SOJA, 2013). No entanto, a aplicação dessa estratégia de inoculação depende de alguns fatores, como a habilidade da bactéria em sobreviver na semente, dos produtos adicionados no tratamento e das condições de armazenamento das sementes. Esses fatos tem limitado o uso dessa prática no Brasil (DATE, 2001).

Atualmente no Brasil a adubação nitrogenada é pouco recomendada e geralmente não excedem o limite de $20 \mathrm{~kg} / \mathrm{ha}$, pois na maior parte das vezes a FBN supre as necessidades de $\mathrm{N}$ da planta. (HUNGRIA, 1999; VARGAS; HUNGRIA, 1997). Com isso, apenas na soja a FBN trouxe consigo uma economia anual estimada de US\$ 3 bilhões em fertilizantes nitrogenados no país, apenas utilizando inoculantes com Bradyrhizobium (FAGAN et al., 2007).

Vários autores relataram que a prática de reinoculação tem atingido resultados variados, nos quais alguns mostram aumento de produtividade (BIZARRO, 2008), já outros não possuem nenhuma resposta, provavelmente devido ao fato de que as populações de Bradyrhizobium que existem no solo já apresentavam estirpes eficientes e em número apropriado (CAMPOS; GNATTA, 2006; PAVANELLI; ARAÚJO, 2009).

Além do alto custo, outro problema na utilização de fertilizantes nitrogenados é a baixa eficiência da assimilação da uréia pelas plantas, dificilmente ultrapassando $50 \%$ de rendimento, pois ao ser aplicado diretamente no solo ocorre a degradação da mesma pela presença da urease, com posterior perda de $\mathrm{N}$ por lixiviação e volatização. É necessário também levar em conta o prejuízo ambiental causado pelo uso indiscriminado desses fertilizantes, pois devido ao processo de lixiviação do $\mathrm{N}$ pelo solo ocorre acúmulos de formas nitrogenadas em rios e lençóis subterrâneos, onde podem atingir níveis tóxicos e causar diversas doenças. Problemas respiratórios já foram associados ao consumo de água contaminado com nitrato em países da Europa. (HUNGRIA et al., 2001).

Diante disso, nesse trabalho objetivou-se avaliar a produtividade e outras características agronômicas de plantas originadas de sementes inoculadas com aditivo de um bioprotetor previamente ao plantio em diferentes períodos, na região de Sinop-MT.

\section{Material e metódos}

O ensaio foi conduzido na cidade de SinopMT, nas coordenadas $11^{\circ} 13^{\prime} 53^{\prime \prime}$ sul e $55^{\circ} 18^{\prime} 20^{\prime \prime}$ oeste, com altitude de 317 metros, localizado na fazenda São Benedito. O clima da região, conforme Köppen e Geiger é classificado como Am, com uma estação chuvosa que começa em setembro/outubro 
e dura até abril/maio e uma temperatura média anual de $25,4^{\circ} \mathrm{C}$, a precipitação media é $1801 \mathrm{~mm}$ anuais, sendo que o valor de precipitação durante 0 ciclo da cultura foi de $1188 \mathrm{~mm}$. (SOUZA et al., 2013).

A semeadura da soja ocorreu no dia 18 de outubro de 2019 e a colheita realizada no dia 06 de fevereiro de 2020. A cultivar utilizada foi a Monsoy 8372 IPRO da Monsoy®, de crescimento determinado, com ciclo na microrregião 401 Médio norte de Mato Grosso entre 110 e 120 dias, a planta caracteriza-se por possuir boa estrutura de galhos e alta produtividade, média exigência em fertilidade e resistência ao nematoide de cistos raça 1, 3, 6 e 10 além de um desenvolvimento radicular robusto e boa sanidade foliar (MONSOY, 2020).

Foram feitas no total cinco diferentes datas de inoculação das sementes com o produto Nitragin Optimize Power® da BioAg, além da testemunha. Junto com o inoculante líquido para soja, que possui em sua formulação uma alta concentração de bactérias Bradyrhizobium japonicum com um mínimo de 3 bilhões de células ativas por $\mathrm{mL}$, o produto acompanha um bioaditivo e bioprotetor chamado Nitragin BioPower ${ }^{\circledR}$, com formulação em microemulsão que facilita a distribuição uniforme do produto sobre as sementes e age como osmoprotetor e antidessecante, responsável pela proteção bacteriana aos produtos fitossanitários. Segundo a empresa fabricante, esse bioaditivo também age como meio de cultura para a bactéria, que quando colocado junto com os rizóbios na semente, geram condições de crescimento da população bacteriana.

As sementes foram tratadas com StandakTop® $(90 \mathrm{~mL} / 50 \mathrm{~kg}$ de sementes) e cobalto + molibdênio com o produto CoMo Platinum $\AA$ (80 $\mathrm{mL} / 50 \mathrm{~kg}$ de sementes). Depois da aplicação dos agroquímicos nas sementes, foi aguardado um tempo para a secagem dos mesmos e então foi feita a inoculação em uma segunda operação, utilizado na dose de $150 \mathrm{~mL}$ para cada $50 \mathrm{~kg}$ de sementes, além de $70 \mathrm{~mL} / 50 \mathrm{~kg}$ de sementes do produto bioprotetor.

O delineamento experimental utilizado foi inteiramente casualizado com 6 tratamentos, sendo eles a pré-inoculação feita em 5 períodos: $(1,4,6,7$ e 8 dias antes da semeadura), e a testemunha (recebeu apenas tratamento químico de sementes, sem a aplicação do inoculante). As sementes foram armazenadas em um barracão protegidas do sol e a temperatura ambiente após receberem o tratamento químico. O plantio de todos os tratamentos, inclusive o da testemunha, foi realizado no mesmo dia e sob as mesmas condições. Cada tratamento possuía uma faixa com três linhas plantadas de 100 metros de comprimento cada e espaçadas $50 \mathrm{~cm}$ entre si, totalizando uma área total de $150 \mathrm{~m}^{2}$ para cada tratamento e nos limites do experimento foram plantadas várias linhas sem inoculação de cada lado para efeito de bordadura.

O manejo da cultura foi realizado junto com todas as demais atividades da área, a diferença foi apenas na colheita que foi feita manualmente. $O$ preparo do solo foi realizado 25 dias antes do plantio com a aplicação de $180 \mathrm{~kg} / \mathrm{ha}$ do fertilizante 00-18-18. O manejo de daninhas pré-plantio foi feito com a pulverização de $30 \mathrm{~g} /$ ha de Clorumiron 250 WG® e $2 \mathrm{~kg} / \mathrm{ha}$ de $\mathrm{Wg}$ glifosato. No plantio também foram utilizados $170 \mathrm{~kg} / \mathrm{ha}$ de $\mathrm{KCl}$.

Para o controle de percevejos foi aplicado $800 \mathrm{ml} /$ ha de Piretróide + Imidacloprido e para 0 controle de lagartas $60 \mathrm{ml} / \mathrm{ha}$ de Permetrina 384 EC® junto com Ampligo® a 50ml/ha. A aplicação de fungicidas foi feita com 250ml/ha de Galilß (imidacloprido e bifenthrin) e $500 \mathrm{ml} / \mathrm{ha}$ de Opera® (Epoxiconazole + Pyraclostobin).

Após 32 dias do plantio foi realizada uma aplicação onde utilizou-se as doses de $500 \mathrm{ml}$ Active® (fonte de nitrogênio e fósforo), 160ml de Fastac® (alfa-cipermetrina), e 500ml de manganês Active $\AA$ (fonte de nitrogênio e fósforo) por hectare.

A segunda aplicação ocorreu no $45^{\circ}$ dia da cultura, foram utilizados $250 \mathrm{~mL} /$ ha de Orkestra ${ }^{\circledR}$ (fluxapiroxade e piraclostrobina), $480 \mathrm{~mL} / \mathrm{ha}$ de Status ${ }^{\circ}$ (oxicloreto de cobre), 165mL/ha de Nomolt ${ }^{\circledR}$ (teflublenzurom), $300 \mathrm{~mL} / \mathrm{ha}$ de Galilß (imidacloprido e bifenthrin), 0,5mL/ha de TEK-F® (adjuvante) e $300 \mathrm{~mL} /$ ha Assist@ (óleo mineral).

Para as avaliações foram feitas duas coletas em datas diferentes, na primeira, 32 dias após o plantio, foi feita a medição do teor de clorofila, contagem de galhos e folhas, além da área foliar das amostras. As faixas dos tratamentos foram divididas em quatro subfaixas, cada uma com 25 metros de comprimento contemplando as três linhas espaçadas por 50 centímetros, totalizando uma área de $37,5 \mathrm{~m}^{2}$ de cada. Para obtenção dessas características foram então retiradas quatro covas de cada tratamento de modo aleatório, uma de cada subfaixa, somando um total de 8 plantas analisadas por tratamento.

A medição do teor de clorofila foi feita antes da coleta do material, nas mesmas plantas que seriam retiradas posteriormente para analises, medindo uma folha de cada planta com o auxílio de um clorofilômetro da marca comercial ClorofiLOG® modelo CFL 1030, o qual apresenta os resultados em um índice próprio denominado ICF: Índice de Clorofila Falker (FALKER, 2008).

Após a medição as plantas foram coletadas, acondicionadas em sacos de papel "kraft" e levadas ao laboratório de Nutrição e Alimentação Animal da UFMT, Campus de Sinop, para a avaliação das outras variáveis vegetativas. No laboratório, as folhas foram destacadas e contadas, obtendo-se o número de folhas por plantas, número de galhos e a área foliar em $\mathrm{cm}^{2}$, com o auxílio de um Integrador de área foliar LICOR modelo LI $-3010 \AA$.

No dia da colheita foi realizada outra coleta, apanhando quatro amostras de cada tratamento, sendo uma de cada subfaixa como na primeira coleta. A colheita foi feita manualmente coletando linhas de três metros cada entre a primeira e a última planta. Logo após o material foi ensacado, 
separado e identificado a qual parcela pertenciam e então encaminhadas para trilha mecanizada. Depois de trilhados foi feita a retirada de impurezas e então colocados na estufa a $75^{\circ} \mathrm{C}$ por 24 horas. Apenas depois disso foi realizada a pesagem da massa dos grãos de cada parcela e posteriormente feito o cálculo da produtividade por hectare. A massa de mil grãos foi estimada pela pesagem de 100 grãos de cada parcela, tendo o valor em gramas da sua pesagem multiplicada por 10 .

O número médio de grãos por vagens das amostras foi obtido antes da trilhagem do material, contando os legumes de 12 plantas por repetição selecionadas aleatoriamente.

Os dados obtidos foram submetidos ao teste $\mathrm{F}$ de análise de variância e Regressão a 5\% de probabilidade, com o software estatístico SISVAR® (FERREIRA, 2011).

\section{Resultados e discussões}

Para o número de grãos por vagem e teor de clorofila não foram observadas diferenças estatística entre os tratamentos (Figura 1). Bulegon et al., (2016) relatou resultado parecido em experimento de inoculação, o qual não constatou efeito significativo da interação entre tratamentos para a variável número de grãos por vagem. As vagens necessitam de grandes quantidades de $\mathrm{N}$ para sua formação, sendo que geralmente nessa fase há uma redistribuição do nutriente na planta (Ryle et al., 1979). Tendo em vista que os grãos de soja apresentam em média 6,5\% de $\mathrm{N}$ (Mendes et al., 2007), o número de grãos por vagem é uma característica que pode indicar o acúmulo de $\mathrm{N}$ pela planta causada pela simbiose. Porém segundo Mundstock e Thomas (2005) esse componente de produtividade é o que mostra menor variação entre diversos manejos de cultivos, mostrando uma regularidade do melhoramento genético na busca do aumento da produção média de grãos por legume. O estudo de Silva et al., (2011) também constatou o mesmo resultado desse trabalho comparando aplicação de inoculantes com adubação nitrogenada, não mostrando diferença estatística nas médias da variável. Não foram notadas diferenças na arquitetura da parte aérea das plantas entre tratamentos.

Um importante indicativo da eficiência da simbiose entre a planta e as bactérias fixadoras de $\mathrm{N}$ que não foi considerado nesse estudo é a presença e quantidade de nódulos nas raízes, que é enfatizada por Vollmann et al. (2011) que indicou sua relação com o aumento do teor de clorofila nas folhas. Além disso, também apresentaram correlação com a produtividade de grãos (BRANDALERO et al., 2009).

Nesse estudo não houve diferença estatística para a variável teor de clorofila (Figura 2), os tratamentos que apresentaram maiores médias foram os inoculados 4 e 1 dias antes da semeadura, respectivamente, mostrando certa eficiência da pré-inoculação nos níveis de clorofila das plantas, apesar da testemunha apresentar média maior do que os outros 3 tratamentos.

Assim como constatou Fipke, (2015) diferentes datas de inoculação pouco afetaram 0 teor de clorofila das plantas, não obtendo nenhuma diferenciação estatística observada. Devido à alta correlação entre o teor de nitrogênio nas plantas e o teor de clorofila (ARGENTA et al., 2001), essa avaliação é válida a fim de testar a eficiência das bactérias diazotróficas (PEREIRA et al., 2010). Também foi relatado que tratamentos que receberam a aplicação de osmoprotetor obtiveram número de nódulos significativamente maiores comparados com tratamentos que receberam inoculação mas não foi utilizado o produto. (FIPKE, 2015).

Para o número de folhas (Gráfico 3), os ensaios com inoculação realizada mais distantes da semeadura apresentaram os menores valores, além de figurarem entre as piores médias de área foliar, mostrando uma deficiência do efeito significativo do tempo de contato da bactéria com o meio de cultura presente no produto para essa variável. O tratamento inoculado 1 dia antes da semeadura, que geralmente é o mais recomendado a se fazer, foi o que apresentou maior média de número de folhas, se mostrando eficiente na absorção dos nutrientes oferecidos pela inoculação precoce, porém não conseguiu comportar esse aumento na sua área foliar, característica na qual obteve uma das piores médias entre os tratamentos. Observando os resultados das análises das características foliares, as únicas que apresentaram diferenças estatísticas entre os tratamentos no estudo, notou-se a eficiência do tratamento inoculado 4 dias antes da semeadura, o qual apresentou a segunda maior média de número de folhas e a maior média de área foliar, mostrando que foi o período que melhor comportou a absorção de nutrientes causada pela simbiose nos quesitos foliares, o que possivelmente trouxe vantagens para a cultura principalmente pela maior absorção de radiação solar, levando em conta que também foi o tratamento que obteve a maior média de teor de clorofila.

O rendimento da soja testá ligado à capacidade das plantas de captarem a radiação solar através do índice de área foliar e pelo processo fotossintético converter essa radiação em matéria seca (ZANON et al., 2015), e como o nitrogênio é um nutriente acumulado nas folhas de soja até a fase de formação de vagens (EMBRAPA, 2020), a inoculação seria um processo capaz de afetar os índices de área foliar das plantas devido seu aumento de absorção do nutriente em questão, e apesar de nesse estudo alguns tratamentos inoculados apresentaram índices menores do que o esperado, os tratamentos inoculados 4 e 6 dias antes da semeadura apresentaram aumento considerável desse indicativo, mostrando que 0 contato da bactéria com o meio de cultura presente no produto apresentou resultados positivos para essa váriavel nesses tratamentos, com ressalva 
aos tratamento feitos 7 e 8 dias antes da semeadura, que tiveram o maior tempo de contato entre bactéria e o meio de cultura porém apresentaram médias de área foliar e de número de folhas piores que a própria testemunha.

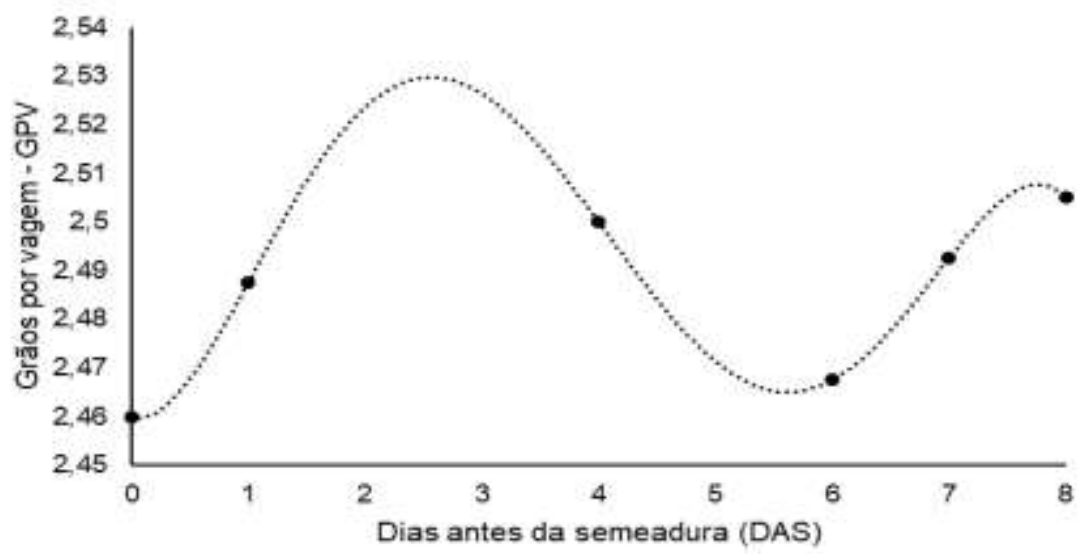

Figura 1: valores médios dos números de grãos por vagem de soja da cultiva 8372, inoculadas em diferentes dias antes da semeadura (DAS).

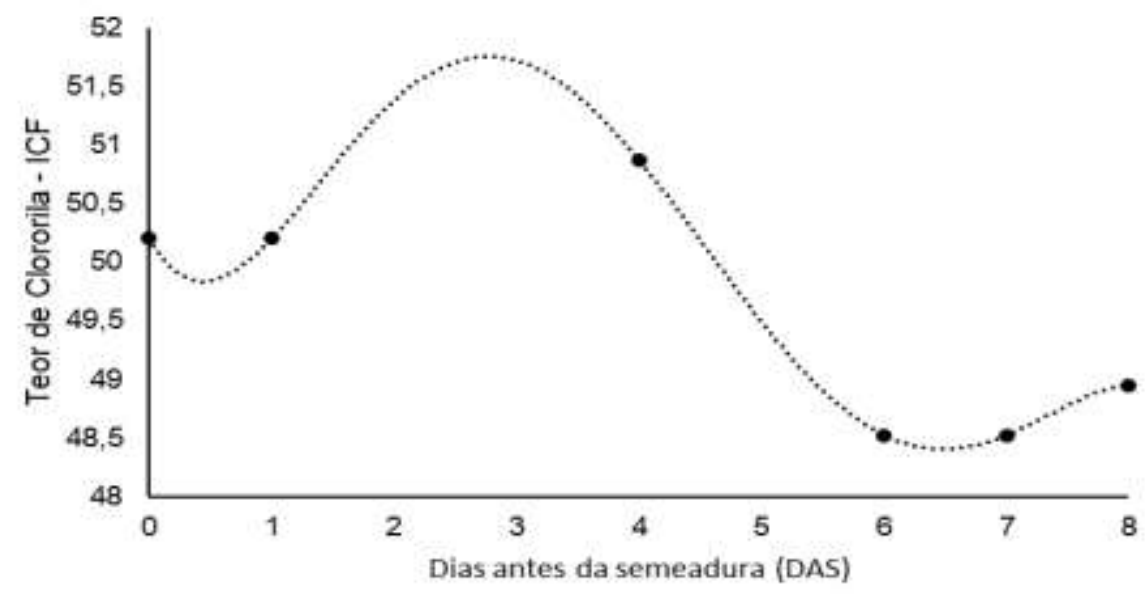

Figura 2. Valores médios do teor de clorofila de soja da cultivar 8372, inoculadas em diferentes dias antes da semeadura (DAS).

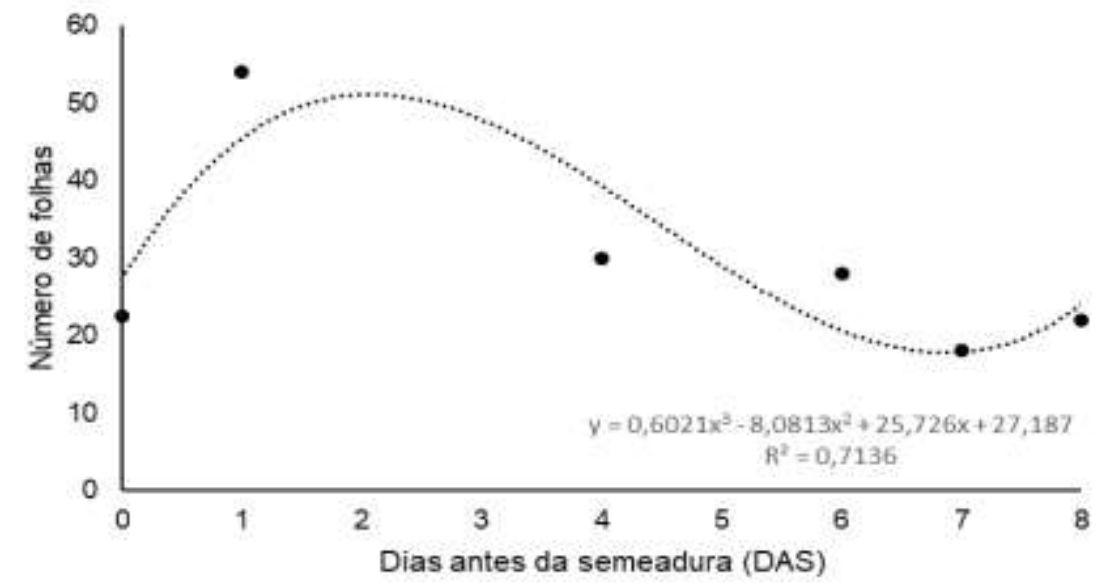

Figura 3. Valores médios do número de folhas de soja da cultivar 8372 , inoculadas em diferentes dias antes da semeadura (DAS). 


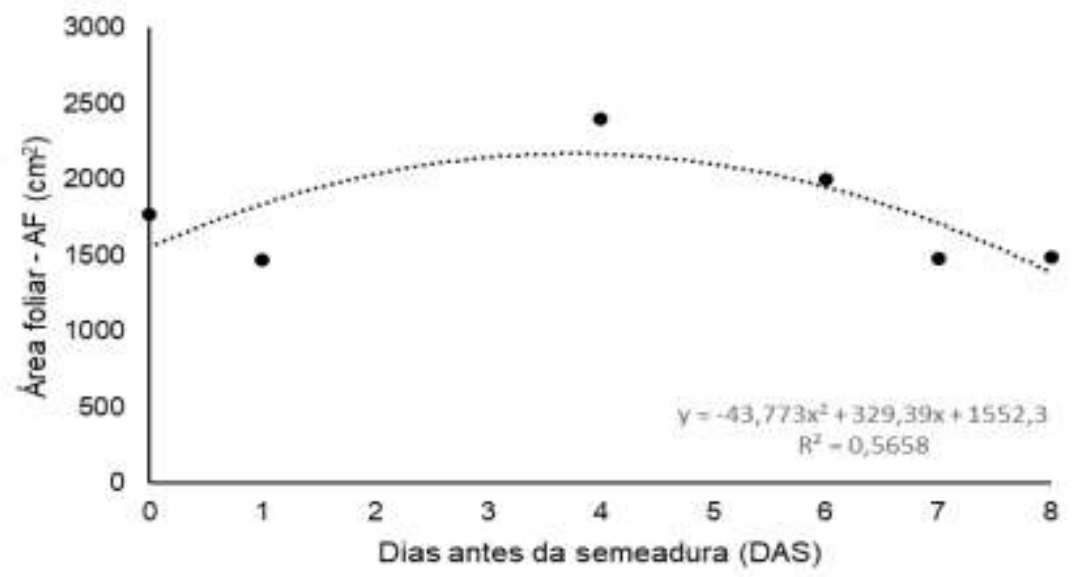

Figura 4. Valores médios de área foliar $\left(\mathrm{cm}^{2}\right)$ de amostras de soja da cultivar 8372, inoculadas em diferentes dias antes da semeadura

A presença dos nódulos, estruturas responsáveis pela simbiose entre a planta e bactéria, é um indicativo da ocorrência da fixação biológica de $\mathrm{N}$ que acontece na planta, e ela foi observada nos tratamentos inoculados, indicando que houve sucesso na inoculação utilizando produto bioprotetor mesmo com a presença de fungicida na semente, o que possivelmente trouxe maior absorção do nutriente pelas plantas, apesar de não terem sido observadas diferenças significativas de acúmulo de $\mathrm{N}$ na matéria seca entre tratamentos inoculados e não inoculados em outros trabalhos (ZILLI et al., 2009).

Para a variável número de galhos (Figura 5) não houve diferenças significativas entre os tratamentos, com os maiores valores observados nos ensaios inoculados 4, 6 e 8 dias antes da semeadura. $O$ tratamento inoculado 7 dias antes da semeadura obteve a pior média igualando-se a testemunha. $O$ ensaio inoculado 4 DAS apresentou a maior média também nessa característica, indicando ser um dos tratamentos mais eficazes no aumento do crescimento vegetativo da cultura. Segundo Mauad et al., (2010) o maior número de nós se relaciona a plantas de soja mais produtivas, levando em conta que em cada nó ocorre a diferenciação de gemas reprodutivas que se tornam vagens após a fecundação. Em vista disso, quanto menor o número de nós, menor o potencial da planta para produzir vagens.

Segundo Sementes Maua (2015) o número de galhos apresenta relação com a quantidade de vagens, contando que a planta da soja apresenta as vagens em seus nós, e plantas mais altas e com maior número de galhos possivelmente terão mais nós, assim também tendo maior chance de possuírem maior quantidade de vagens. Levando em conta as variáveis número de galhos e número de folhas, fica evidenciado o efeito da inoculação feita mais distante do plantio, mostrando que os tratamentos inoculados mais previamente mostraram os melhores resultados nessas características.
Para a variável peso de mil grãos (Figura 6) também não houve variação estatística entre os tratamentos, sendo observado que as inoculações mais distantes da semeadura apresentaram as melhores médias, já o tratamento inoculado 4 DAS, que apresentou os melhores resultados de crescimento vegetativo da planta, mostrou a pior média do experimento nos pesos dos grãos, sendo inferior inclusive que a da própria testemunha, indicando que não comportou tão bem a absorção de nutrientes para o enchimento dos grãos como para as outras características. $O$ estudo de Anghinoni, (2016) relatou resultados um pouco diferentes, sendo observado aumento dos números dessa característica de todos os tratamentos de pré-inoculação na comparação com a testemunha. Sendo que os valores de peso de mil grãos da cultura podem ser influenciados pela cultivar usada e também pelas condições de manejo da área, eles tendem a variar geralmente entre 140 a $220 \mathrm{~g} / 1000$ grãos (PIONEER SEMENTES, 2019). Nesse estudo não foi observada nenhuma média abaixo $170 \mathrm{~g} / 1000$ grãos, o que demonstra uma boa nutrição da planta principalmente na fase de enchimento de grãos. Diante disso, é possível dizer que houve bom suprimento de $\mathrm{N}$ durante $\mathrm{O}$ desenvolvimento da cultura.

As médias de produtividade (Figura 7) não apresentaram diferenças estatisticamente significativas, tendo a maioria dos tratamentos inoculados mostrado maior rendimento em relação à testemunha, com excessão do tratamento habitual inoculado 1 DAS que obteve a menor média. Benedet, (2016) constatou resultado semelhante com sementes inoculadas até 60 dias antes do plantio com utilização de protetor celular e defensivos químicos que obtiveram números de produtividade semelhantes ao controle sem inoculante. Os maiores resultados foram observados nos ensaios inoculados mais longe do plantio, com 6,7 e 8 dias de pré-inoculação apresentando as maiores médias, respectivamente. 
Pereira et al. Produtividade com sementes pré-inoculadas de soja em períodos antes da semeadura

Tabela 1. Análise de variância e regressão para as variáveis grão por vagem (GPV), teor de clorofila (ICF), apontador de folhas (№ folhas) e área foliar (AF).

\begin{tabular}{lccccc}
\hline FV & GL & \multicolumn{3}{c}{ Quadrados médios } \\
\cline { 3 - 6 } & & GPV & ICF & № folhas & AF \\
\hline Datas de plantio & 5 & 0,001 & 4,049 & $659,466^{*}$ & $559541,46^{*}$ \\
Blocos & 3 & 0,003 & 2,4248 & 14,833 & 462443,67 \\
Erro & 15 & 0,002 & 7,072 & 31,600 & 168364,60 \\
\hline Total & 23 & & & & 33776,46 \\
\hline Reg. Linear & 1 & - & - & 388,35 & $1549133,23^{*}$ \\
Reg. Quadrática & 1 & - & - & 11,22 & 72233,41 \\
Reg. Cúbica & 1 & - & - & 19,11 & 23,20 \\
\hline CV (\%) & & 2,07 & 5,37 & 29,41 & 1768,66 \\
Média geral & & 2,48 & 49,54 & & \\
\hline
\end{tabular}

${ }^{*}$ diferenças significativas a $1 \%$ de probabilidade pelo teste $\mathrm{F}$

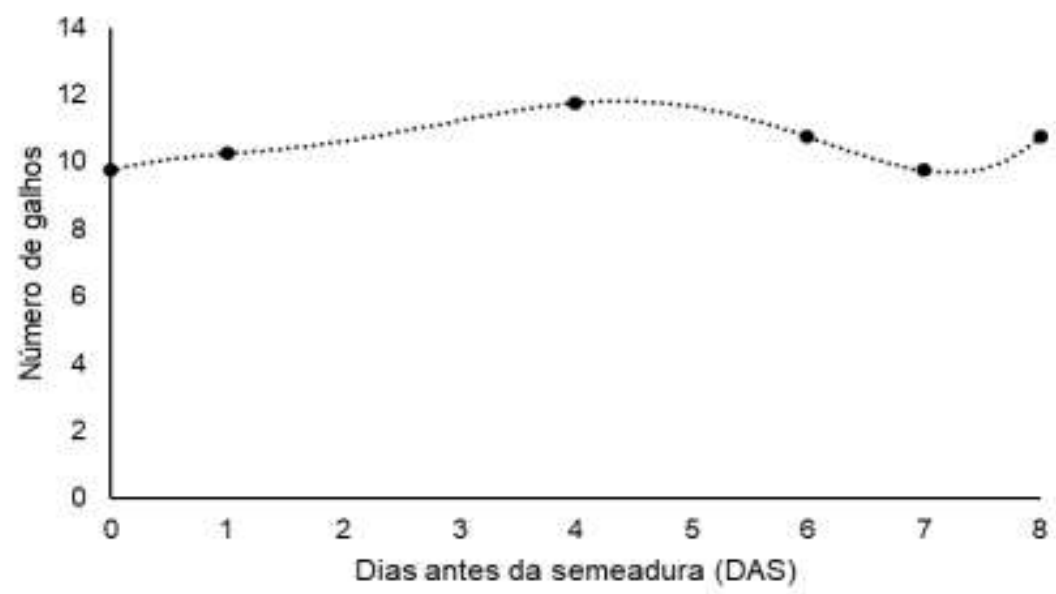

Figura 5. Valores médios do número de galhos de soja da cultivar 8372 , inoculadas em diferentes dias antes da semeadura (DAS)

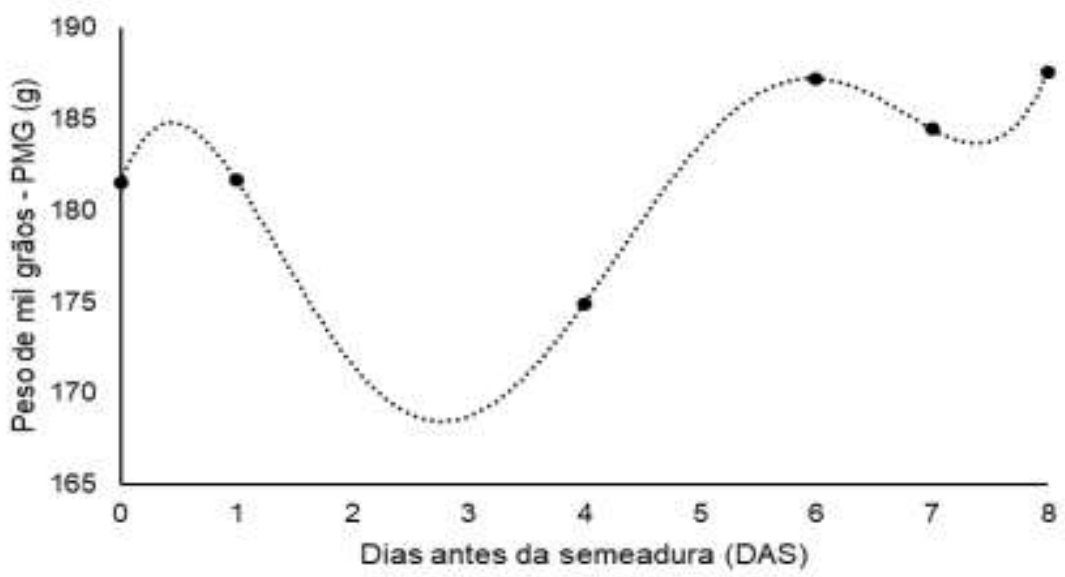

Figura 6. Valores médios de peso de mil grãos (PMG) de soja da cultiva M8372, inoculadas em dias diferentes antes da semeadura (DAS) 


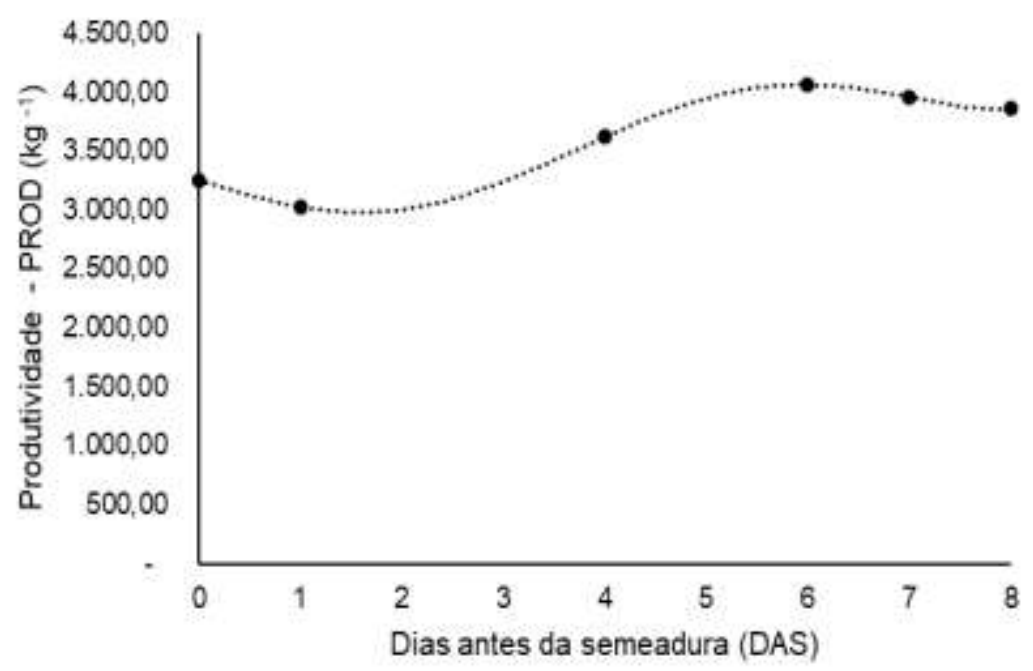

Figura 7. Valores médios de produtividade (kg/ha) de soja da cultivar M8372, inoculadas em diferentes dias antes da semeadura (DAS)

Tabela 2. Análise de variância e regressão para as variáveis), número de galhos (№ galhos), peso de mil grãos (PMG) e produtividade (PROD).

\begin{tabular}{lcccc}
\hline FV & GL & \multicolumn{3}{c}{ Quadrados médios } \\
\cline { 3 - 5 } & & No galhos & PMG & PROD \\
\hline Datas de plantio & 5 & ${ }^{n s} 2,3000$ & ${ }^{n s} 88,3876$ & 685954,2416 \\
Blocos & 3 & 1,6667 & 6,5938 & 168662,4861 \\
Erro & 15 & 1,7000 & 60,8478 & 961527,8194 \\
\hline Total & 23 & & & - \\
\hline Reg. Linear & 1 & - & - & - \\
Reg. Quadrática & 1 & - & - & - \\
Reg. Cúbica & 1 & - & 4,26 & 27,02 \\
\hline CV (\%) & & 12,42 & 182,90 & 3628,5417 \\
Média geral & 10,50 & & \\
\hline
\end{tabular}

Apesar da inexistência de diferenciação estatística, os resultados indicam aumentos de produção com a prática, mostrando ganhos de até $700 \mathrm{~kg} / \mathrm{ha}$ com a prática de pré-inoculação.O fato de a área utilizada no experimento possuir um histórico de cultivos anteriores de soja pode ser a explicação para essa ausência de diferenças, levando em conta que possivelmente ela deve conter populações de rizóbios eficientes já estabelecidas, o que colonizaria o controle não inoculado e assim igualando-o aos demais tratamentos. Foi constatado por Zilli et al., (2006), que trabalhando com inoculação na soja em áreas de primeiro cultivo, tratamentos inoculados apresentaram produtividade estatisticamente iguais ao tratamento com adubação nitrogenada, mostrando a eficiência da fixação biológica de $\mathrm{N}$ causada por essas bactérias e a importância de introduzi-las ao solo promovendo estabelecimento de sua população.

Os ganhos de produtividade em áreas que já foram cultivadas com bradirizóbios se mostram expressivos quando comparados com áreas que não possuem populações estabelecidas do mesmo (BENEDET, 2016). O que justifica que a presença dessas bactérias já existentes no solo do experimento impossibilitou a observação de diferenças de produção entre os tratamentos. Além disso, possivelmente 0 solo utilizado no experimento forneceu assistência nutricional para o desenvolvimento da planta através de sua fertilidade, incluindo teores de $\mathrm{N}$ já existentes nele, o que contribuiria com tratamentos sem inoculante.

\section{Conclusões}

O uso de inoculantes junto com protetor celular em sementes contribui para o aumento do crescimento vegetativo da soja quando é realizado em no máximo 4 dias antes da semeadura, principalmente para o aumento da área foliar e do número de folhas.

Os tratamentos inoculados mais distantes da semeadura apresentaram os menores índices de crescimento vegetativo, porém foram os que melhores responderam no quesito da massa dos grãos e na produtividade, apresentando as melhores médias.

Apesar dos ganhos na produção, a préinoculação não promoveu variação estatística mesmo com o uso do bioprotetor, tornando difícil realizar uma recomendação garantida do produto.

\section{Referências}

ANGHINONI, F. B. G. Avaliação da eficiência da pré-inoculação com Bradyrhizobium spp. em sementes de soja tratadas industrialmente. 2016. 
Dissertação de Mestrado. Universidade Estadual de Maringá.

BÁRBARO, I. M. et al. Produtividade da soja em resposta à inoculação padrão e co-inoculação. In: Colloquium Agrariae. ISSN: 1809-8215. 2009. p. 01-07.

BENEDET, G. L. Avaliação da eficiência agronômica de inoculante líquido comercial para pré-inoculação de sementes de soja com tratamento químico até 60 dias antes do plantio e utilização de protetor celular. 2016.

BIGATON, D. Fungicidas e micronutrientes aplicados em tratamento de sementes de soja (Glycine max (L.) Merrill) e seus efeitos sobre a nodulação e a fixação biológica do N. 2005. 43 p. Dissertação (Mestrado em Agronomia/Produção Vegetal) - Universidade Federal do Mato Grosso do Sul, Dourados, MS.

BULEGON, L. G. et al. Componentes de produção e produtividade da cultura da soja submetida à inoculação de Bradyrhizobium e Azospirillum. Terra Latinoamericana, v. 34, n. 2, p. 169-176, 2016.

BULEGON, L. G. et al. Componentes de produção e produtividade da cultura da soja submetida à inoculação de Bradyrhizobium e Azospirillum. Terra Latinoamericana, v. 34, n. 2, p. 169-176, 2016.

CHUEIRE, L. M. O. et al. Classificação taxonômica das estirpes de rizóbio recomendadas para as culturas da soja e do feijoeiro baseada no seqüenciamento do gene 16S rRNA. Revista Brasileira de Ciência do Solo, v.27, n.5, p.883-840, set./out. 2003.

DA SILVA, A. F. et al. Doses de inoculante e nitrogênio na semeadura da soja em área de primeiro cultivo. Bioscience Journal, v. 27, n. 3 , 2011.

DALL'AGNOL, A. et al. O complexo agroindustrial da soja brasileira. Embrapa Soja-Circular Técnica (INFOTECA-E), 2007.

DO AMARANTE, L. et al. Teores de clorofilas em soja associada simbioticamente com diferentes estirpes de Bradyrhizobium sob alagamento. Revista Brasileira de Biociências, v. 5, n. S2, p. 906-908, 2007.

FAGAN, E. B. et al. Fisiologia da fixação biológica do nitrogênio em soja-Revisão. Revista da FZVA, v. 14, n. 1, p. 89-106, 2007.

FERREIRA, E. et al. Nova legislação, recomendação de doses de inoculantes e préinoculação: riscos ao sucesso da contribuição da fixação biológica do nitrogênio para a cultura da soja. In: Embrapa Soja-Artigo em anais de congresso (ALICE). In: REUNIÃO DE PESQUISA DE SOJA DA REGIÃO CENTRAL DO BRASIL, 32., 2011, São Pedro, SP. Resumos expandidos... Londrina: Embrapa Soja, 2011. p. 325-327.

FERREIRA, E. et al. Nova legislação, recomendação de doses de inoculantes e préinoculação: riscos ao sucesso da contribuição da fixação biológica do nitrogênio para a cultura da soja. In: Embrapa Soja-Artigo em anais de congresso (ALICE). In: REUNIÃO DE PESQUISA DE SOJA DA REGIÃO CENTRAL DO BRASIL, 32., 2011, São Pedro, SP. Resumos expandidos... Londrina: Embrapa Soja, 2011. p. 325-327.

FERREIRA, D. F. Sisvar: A computer statistical analysis system. Ciência e Agrotecnologia, v. 35, n. 6, p. 1039-1042, 2011.

FIPKE, G. M. et al. Co-inoculação e pré-inoculação de sementes em soja. 2015.

FREITAS, R. E.; MENDONÇA, M. A. A. de. Expansão Agrícola no Brasil e a Participação da Soja: 20 anos. Revista de Economia e Sociologia Rural, v. 54, n. 3, p. 497-516, 2016.

GUIMARÃES, S. L.; BALDANI, Vera Lúcia Divan; JACOB-NETO, J. Viabilidade do inoculante turfoso produzido com bactérias associativas $e$ molibdênio. Revista Ciência Agronômica, v. 44, n. 1, p. 10-15, 2013.

HOPKINS, W.G. 1999. Introduction to Plant Physiology. New York, John Wiley \& Sons, Inc. 512 p.

HUNGRIA, M.; CAMPO, Rubens J.; MENDES, I. de C. Fixação biológica do nitrogênio na cultura da soja. Embrapa Soja-Circular Técnica (INFOTECAE), 2001.

HUNGRIA, Mariangela; CAMPO, Rubens José; MENDES, lêda Carvalho. A importância do processo de fixação biológica do nitrogênio para a cultura da soja: componente essencial para a competitividade do produto brasileiro. Embrapa Soja-Documentos (INFOTECA-E), 2007.

MARCON, Evelin Cristina et al. Uso de diferentes fontes de nitrogênio na cultura da soja. Revista Thema, v. 14, n. 2, p. 298-308, 2017

MARIN, Victor Augustus et al. Fixação biológica de nitrogênio: bactérias fixadoras de nitrogênio de importância para a agricultura tropical. 1999.

MARKS, Bettina Berquo et al. Evaluation of survival bradyrhizobium SPP in soybean seed treated with fungicides, guard and cellular inoculant/Avaliacao da sobrevivencia de bradyrhizobium SPP em sementes de soja tratadas com fungicidas, protetor 
celular e inoculante. Revista Internacional de Ciências, 2013.

NOGUEIRA, M. A.; HUNGRIA, M. Boas práticas de inoculação em soja. In: Embrapa Soja-Artigo em anais de congresso (ALICE). In: REUNIÃO DE PESQUISA DA SOJA DA REGIÃO SUL, 40., Pelotas, 2014. Atas e Resumos. Pelotas: Embrapa Clima Temperado, 2014.

SILVA, V. H. da et al. Doses complementares de inoculante Bradyrhizobium japonicum via foliar em diferentes estádios fenológicos na cultura de soja. 2019.

VIEIRA NETO, S. A. et al. Formas de aplicação de inoculante e seus efeitos sobre a nodulação da soja. Revista Brasileira de Ciência do Solo, v. 32, n. 2, p. 861-870, 2008.

YODER, B. J. \& PETTIGREW-CROSBY, B. E. 1995. Predicting nitrogen and chlorophyll content and concentrations from reflectance spectra (400$2500 \mathrm{~nm}$ ) at leaf and canopy scales. Remote Sens. Environ., 53:199-211

ZANON, A. J. et al. Contribuição das ramificações e a evolução do índice de área foliar em cultivares modernas de soja. Bragantia, v. 74, n. 3, p. 279290, 2015.

ZILLI, J. É. et al. Inoculação da soja com Bradyrhizobium no sulco de semeadura alternativamente à inoculação de sementes. Revista Brasileira de Ciência do Solo, v. 34, n. 6, p. 18751881, 2010. 